\title{
Indirect control of the intracellular nitrate pool of intertidal sediment by the polychaete Hediste diversicolor
}

\author{
Ines M. Heisterkamp, Anja Kamp, Angela T. Schramm, Dirk de Beer, Peter Stief*
}

Max Planck Institute for Marine Microbiology, Celsiusstraße 1, 28359 Bremen, Germany

\begin{abstract}
In an intertidal flat of the German Wadden Sea, a large sedimentary pool of intracellular nitrate was discovered that by far exceeded the pool of nitrate that was freely dissolved in the porewater. Intracellular nitrate was even present deep in anoxic sediment layers where it might be used for anaerobic respiration processes. The origin and some of the ecological controls of this intracellular nitrate pool were investigated in a laboratory experiment. Sediment microcosms were set up with and without the abundant polychaete Hediste diversicolor that is known to stimulate nitrate production by microbial nitrification in the sediment. Additional treatments were amended with ammonium to mimic ammonium excretion by the worms or with allylthiourea (ATU) to inhibit nitrification by sediment bacteria. H. diversicolor and ammonium increased, while ATU decreased the intracellular nitrate pool in the sediment. Microsensor profiles of porewater nitrate showed that bacterial nitrification was enhanced by worms and ammonium addition. Thus, nitrification formed an important nitrate supply for the intracellular nitrate pool in the sediment. The vertical distribution of intracellular nitrate matched that of the photopigments chlorophyll $a$ and fucoxanthin, strongly suggesting that diatoms were the main nitrate-storing organisms. Intracellular nitrate formation is thus stimulated by the interaction of phylogenetically distant groups of organisms: worms enhance nitrification by feeding on particulate organic matter, excreting ammonium and oxygenating the sediment; bacteria oxidise ammonium to nitrate in oxic sediment layers; and diatoms store nitrate intracellularly.
\end{abstract}

KEY WORDS: Intertidal sediment - Wadden Sea · Nitrogen cycle · Intracellular nitrate · Microphytobenthos $\cdot$ Macrofauna $\cdot$ Nereis diversicolor $\cdot$ Trophic interaction

Resale or republication not permitted without written consent of the publisher

\section{INTRODUCTION}

Several phylogenetically distant groups of sediment microorganisms are able to store nitrate in their cells. Large sulphur bacteria (Schulz \& Jørgensen 2001), foraminifera (Risgaard-Petersen et al. 2006, Piña-Ochoa et al. 2010) and microalgae (GarciaRobledo et al. 2010, Kamp et al. 2011) store nitrate at millimolar concentrations, while in their direct environment, porewater nitrate is available only at micromolar concentrations. Thus, the uptake of nitrate into the cell occurs against a steep concentration gradient and costs metabolic energy (Høgslund et al. 2008).
Storage of nitrate is of obvious advantage in environments with fluctuating nutrient concentrations. Also, intracellular nitrate is known to be used for respiration in anoxic sediment layers. The high nitrate storage capacity of large sulphur bacteria enables them to survive long periods of anoxia when intracellular nitrate is respired to ammonium (Preisler et al. 2007, Høgslund et al. 2009). Respiratory use of intracellular nitrate has recently also been shown for microeukaryotes such as foraminifera (Risgaard-Petersen et al. 2006) and diatoms (Kamp et al. 2011). At the oxic sediment surface, however, diatoms and other microalgae use dissolved inorganic nitrogen (DIN) 
and probably also intracellular nitrate for nitrogen assimilation (Lomas \& Glibert 2000, Sundbäck \& Miles 2000).

The ability to store nitrate intracellularly may be particularly advantageous in intertidal flats, which are very dynamic ecosystems. Benthic organisms must cope with frequent changes in the availability of e.g. light, oxygen and nutrients due to tidal and diurnal rhythms. Another source of perturbation in intertidal flats is the presence of macrofauna that rework large amounts of sediment and the microorganisms therein (e.g. Bouchet et al. 2009). Some polychaetes construct deep-reaching burrows and enhance solute exchange between sediment and the water column due to their ventilation activity (Kristensen 2001). Many species of intertidal macrofauna feed on sediment microorganisms and thereby decrease microbial populations or keep them in the exponential growth phase (Herman et al. 2000, Blanchard et al. 2001). Under such transient conditions, the nitrate storage capacity awards sediment microorganisms with the steady availability of a key nutrient and an energetically favourable electron acceptor. Nitrate-storing microorganisms may thereby gain a competitive advantage over sediment bacteria that lack the ability to store nitrate intracellularly.

Nitrate is supplied to intertidal sediments via the water column or is produced by microbial nitrification at the oxic sediment surface. Nitrate from nitrification diffuses both into the water column and towards anoxic layers in the sediment where it can be anaerobically respired to dinitrogen gas by microbial denitrification. In intertidal sediments, the coupling of nitrification and denitrification can be relatively loose (Jensen et al. 1996). This implies that either denitrification has a substantial nitrate source other than nitrification (e.g. the water column) or that much of the nitrate produced by nitrification does not end up as dinitrogen produced by denitrification. Nitrate-storing microorganisms take up nitrate from the water column or from the nitrification layer of the sediment surface (Sayama 2001). The sedimentary intracellular nitrate pool might be controlled by the rates of nitrogen mineralisation and nitrification in the sediment. Both processes are stimulated by the oxygenation of the sediment by tidal currents and by ventilation of macrofaunal burrows (Kristensen 2001, Nielsen et al. 2004, de Beer et al. 2005). Additionally, some macrofauna species enrich the sediment with organic matter due to their feeding activities (Christensen et al. 2000), but also digest organic matter in their gut, which further enhances mineralisation and ammonium regeneration (Gardner et al. 1993).
In an intertidal flat of the German Wadden Sea, a snapshot measurement revealed a large pool of intracellular nitrate that reached deep into the sediment, well below the very thin photosynthetic layer (de Beer et al. 2005). The sediment was densely populated by diatoms, but also by the burrowing polychaete Hediste (Nereis) diversicolor. Hence, in a laboratory microcosm experiment, the hypothesis was tested that the presence of $H$. diversicolor in intertidal sediment increases the nitrate supply and thereby the size of the sedimentary intracellular nitrate pool via stimulation of nitrification. The experimental treatments were (1) sediment without worms, (2) sediment with worms, (3) sediment without worms, but amended with ammonium to mimic the worms' ammonium excretion and (4) sediment with worms, but amended with the nitrification inhibitor allylthiourea.

\section{MATERIALS AND METHODS}

\section{Origin of sediment and animals}

Sediment was collected in the intertidal flat near Dorum-Neufeld in the German Wadden Sea $\left(53^{\circ} 45^{\prime} \mathrm{N}, 8^{\circ} 21^{\prime} \mathrm{E}\right)$. This site is characterised by mixed sediment (sand/mud) with low porewater sulphide concentrations (Jahn \& Theede 1997) and high densities of epifauna (e.g. the snails Hydrobia ulvae and Littorina littorea) and infauna (e.g. the polychaetes Arenicola marina and Hediste diversicolor). Sediment from the top $25 \mathrm{~cm}$ was sieved through a $0.5 \mathrm{~mm}$ screen to remove macrofauna and shell debris. It was then frozen at $-20^{\circ} \mathrm{C}$ for $30 \mathrm{~h}$ to kill macrofauna juveniles that had passed through the sieve. The defaunated and homogenised sediment was added to 4 recirculating flow-through microcosms (30 cm long $\times 20 \mathrm{~cm}$ wide $\times 10 \mathrm{~cm}$ high). A thin layer of unfrozen and $180 \mu \mathrm{m}$ sieved sediment was evenly distributed on the sediment surface to inoculate the sediments with living microalgae. After the sediment had settled, aerated seawater from the North Sea diluted to the in situ salinity of 22 was continuously directed over the sediment surface. Each microcosm was continuously supplied from its own 501 seawater reservoir at a flow rate of $31 \mathrm{~min}^{-1}$ throughout the experiment. To allow the growth of microalgae on the sediment surface and the formation of the typical redox stratification in the sediment, the flow-through microcosms were illuminated from above by a neon daylight lamp (50 $\mu \mathrm{mol}$ photons $\mathrm{m}^{-2}$ $\mathrm{s}^{-1}$ light intensity at the sediment surface) at a $16 \mathrm{~h}$ 
light to $8 \mathrm{~h}$ dark cycle and left untouched for $10 \mathrm{~d}$. The incubation temperature was $22^{\circ} \mathrm{C}$, which was at the upper end of temperatures reached at the collection site during summer when large infauna are abundant and exhibit high foraging, burrowing and ventilation activities. The polychaete $H$. diversicolor (O.F. Müller) was freshly collected from the intertidal flat near Dorum-Neufeld by digging up the sediment with a spade to a depth of approximately $25 \mathrm{~cm}$ and searching through it by hand. On the day of collection, 30 individuals of 250 to $300 \mathrm{mg}$ wet weight were added to 2 of the 4 microcosms, which corresponded to a density of 420 ind. $\mathrm{m}^{-2}$.

\section{Experimental design}

The experiment comprised 4 treatments (1 in each microcosm): (1) sediment without Hediste diversicolor (Control), (2) sediment colonised by H. diversicolor (Hediste), (3) sediment not colonised by $H$. diversicolor, and overlain with ammonium-enriched water (Ammonium) and (4) sediment colonised by H. diversicolor, and overlain by allylthiourea (ATU)treated water (Hediste + ATU). ATU, an inhibitor of microbial ammonia oxidation (Hall 1984), was added to the seawater at a final concentration of $100 \mu \mathrm{mol}$ $\mathrm{l}^{-1}$ on the day the animals were added. Three days later, $\mathrm{NH}_{4} \mathrm{Cl}$ was added to the seawater of treatment (3) to a final concentration of $50 \mu \mathrm{mol} \mathrm{l}^{-1} \mathrm{NH}_{4}{ }^{+} ; 16 \mathrm{~d}$ later, it was replenished because the concentration had dropped to less than $2 \mu \mathrm{mol} \mathrm{l}^{-1} \mathrm{NH}_{4}{ }^{+}$. Water samples from the 4 microcosms were taken every $2 \mathrm{~d}$ during the course of the experiment and stored at $-20^{\circ} \mathrm{C}$ until ammonium was analysed by flow injection (Hall \& Aller 1992) and nitrate was analysed using the $\mathrm{VCl}_{3}$ reduction method (Braman \& Hendrix 1989) with a chemiluminescence detector (CLD $86 \mathrm{~S}$ $\mathrm{NO} / \mathrm{NO}_{\mathrm{x}}$-Analyser, Eco Physics). Microsensor measurements were started $10 \mathrm{~d}$ after the animals were added and were completed within $11 \mathrm{~d}$. Afterwards, sediment cores were taken for the analysis of intracellular nitrate and photopigments.

\section{Intracellular nitrate}

In the intertidal flat near Dorum-Neufeld that was densely colonised by Hediste diversicolor, 4 randomly selected sediment cores with an inner diameter of $3.6 \mathrm{~cm}$ were taken at low tide. One sediment core was used for measuring porewater nitrate concentration by microsensor measurements (see 'Micro- sensor measurements' below). The other 3 sediment cores were sliced at $0.2 \mathrm{~cm}$ intervals for the upper $1 \mathrm{~cm}$ and at $1 \mathrm{~cm}$ intervals to a total depth of $15 \mathrm{~cm}$. Care was taken to remove macrofauna from each slice with forceps. The sediment slices were frozen at $-20^{\circ} \mathrm{C}$ until used for nitrate extraction with the freeze-and-thaw technique (Lomstein et al. 1990). For the extraction, $1 \mathrm{ml}$ Milli Q water was added to the $0.2 \mathrm{~cm}$ sediment slices (upper $10 \mathrm{~mm}$ ) and $3 \mathrm{ml}$ Milli Q water to the $1 \mathrm{~cm}$ sediment slices (1 to $15 \mathrm{~cm}$ ). Samples were vigorously shaken, frozen in liquid nitrogen and heated in a water bath $\left(90^{\circ} \mathrm{C}\right) 3$ times for 10 min each to physically break up large microbial cells and thereby release intracellular nitrate. The concentration of total nitrate (porewater nitrate plus extracted nitrate) in the supernatant of the sediment slurries was measured using the $\mathrm{VCl}_{3}$ reduction method (Braman \& Hendrix 1989). The intracellular nitrate concentration (expressed in nmol $\mathrm{cm}^{-3}$ sediment) was calculated by subtracting the porewater nitrate concentration from the total nitrate concentration.

In the microcosm experiment, 4 randomly selected sediment cores with an inner diameter of $2.5 \mathrm{~cm}$ were taken from each microcosm and sliced at $0.2 \mathrm{~cm}$ intervals for the upper $1 \mathrm{~cm}$ and at $1 \mathrm{~cm}$ intervals to a total depth of $5 \mathrm{~cm}$. One half of each sediment slice was used for intracellular nitrate analysis and was frozen at $-20^{\circ} \mathrm{C}$, the other half was used for pigment analysis and was frozen at $-80^{\circ} \mathrm{C}$. Extraction and analysis of intracellular nitrate were carried out as described above.

\section{Photopigments}

Sliced sediment from the laboratory microcosms was defrosted, and each slice was incubated with $10 \mathrm{ml} \mathrm{90 \%} \mathrm{acetone} \mathrm{(Sigma-Aldrich)} \mathrm{on} \mathrm{a} \mathrm{rotary}$ shaker at $4^{\circ} \mathrm{C}$ overnight. After centrifugation at $3700 \times g(10 \mathrm{~min})$ at $0^{\circ} \mathrm{C}$, the supernatants were filtered (Acrodisc ${ }^{\circledR}$ CR $4 \mathrm{~mm}$ Syringe Filter with $0.45 \mu \mathrm{m}$ Versapor ${ }^{\circledR}$ Membrane, Gelman Laboratory) and added to high performance liquid chromatography (HPLC) vials. Samples were always kept in the dark. Extracted pigments were separated by means of HPLC (Waters 2695) and analysed by a photodiode array detector (Waters 996). The HPLC column (Reprosil, $350 \times 4.6 \mathrm{~mm}$, Dr. Maisch) was heated to $25^{\circ} \mathrm{C}$, while the samples were kept at $4^{\circ} \mathrm{C}$ during measurements. Pigments of each sample were separated by 3 different eluents (methanol:ammonium acetate [80:20], acetonitrile $90 \%$ and ethyl acetate 
$100 \%$, flow rate $1 \mathrm{ml} \mathrm{min}^{-1}$ ), the mixing ratio of which changed gradually during each 24 min run. Peaks were integrated with the software Millenium ${ }^{32}$, and chlorophyll a ( $\mathrm{chl}$ a) and fucoxanthin peaks were identified according to their specific retention time and absorption spectrum. Calibrations were performed by using 1:5, 1:10, 1:20 and 1:40 dilutions of a chl a stock solution (1.963 $\left.\mathrm{mg} \mathrm{l}^{-1}, \mathrm{DHI}\right)$ and a fucoxanthin stock solution (1.075 $\mathrm{mg} \mathrm{l}^{-1}$, DHI).

\section{Microsensor measurements}

Oxygen and $\mathrm{NO}_{\mathrm{x}}$ microsensors were constructed as described by Revsbech (1989) and Larsen et al. (1997), respectively. The sensors were calibrated before and after each series of 4 to 6 profiles in sterile seawater equilibrated to $22^{\circ} \mathrm{C}$. Oxygen microsensors were calibrated at 0 and $100 \%$ air saturation by flushing the seawater with either dinitrogen gas or synthetic air. $\mathrm{NO}_{\mathrm{x}}$ microsensors were calibrated by adding aliquots of a $10 \mathrm{mmol} \mathrm{l}^{-1}$ stock solution of $\mathrm{NaNO}_{3}$ to a known volume of seawater to arrive at nominal nitrate concentrations of $0,20,40,60,80$ and $100 \mu \mathrm{mol} \mathrm{l} \mathrm{l}^{-1}$. The calibration curve was corrected for the natural concentration of nitrate in the seawater that was determined with the $\mathrm{VCl}_{3}$ reduction method. The oxygen and $\mathrm{NO}_{\mathrm{x}}$ microsensors were simultaneously used in a measuring set-up as described by Stief $\&$ de Beer (2002). At least 4 and up to 14 vertical steady-state concentration profiles were recorded in each flow-through microcosm from $0.3 \mathrm{~cm}$ above to $0.6 \mathrm{~cm}$ below the sediment surface in increments of $0.025 \mathrm{~cm}$. Positions of the profiles were randomly selected, but a minimum distance of $2 \mathrm{~cm}$ to burrow openings at the sediment surface was held in the 2 Hediste treatments. In the natural sediment core from the intertidal flat, profiling with the $\mathrm{NO}_{\mathrm{x}}$ microsensor was done down to a depth of $2 \mathrm{~cm}$ in the laboratory within $2 \mathrm{~h}$ of collection. Profiles were recorded at 3 randomly selected spots of the sediment surface.

The $\mathrm{NO}_{\mathrm{x}}$ profiles were interpreted as porewater nitrate profiles, assuming that nitrite and nitrous oxide $\left(\mathrm{N}_{2} \mathrm{O}\right)$ concentrations in the sediments were negligible. For calculating the depth-integrated nitrate content (see 'Depth integration of data and statistical analysis'), the concentration values in $\mu \mathrm{mol} \mathrm{l}^{-1}$ porewater were converted to concentration values in $\mathrm{nmol} \mathrm{cm}{ }^{-3}$ sediment by multiplication with the average sediment porosity of 0.41 . Local volumetric net nitrate production rates were calculated from the curvature of the steady state $\mathrm{NO}_{\mathrm{x}}$ concentration pro- files by diffusion-reaction modelling (Bungay et al. 1969, Berner 1980). The effective diffusion coefficient of nitrate at depth $x$ in the sediment was calculated as $D_{\mathrm{s}(x)}=D_{0} \times \varphi /\left(1-\ln \left(\varphi^{2}\right)\right)$ (Boudreau 1996), with $D_{0}$ as the diffusion coefficient of nitrate in seawater and $\varphi$ as the sediment porosity. $D_{0}$ of nitrate in seawater was taken as $1.75 \times 10^{-5} \mathrm{~cm}^{2} \mathrm{~s}^{-1}$ at $22^{\circ} \mathrm{C}(\mathrm{Li}$ $\&$ Gregory 1974). $\varphi$ was determined as the volumetric water content of the sediment, which corresponded to the weight loss of sediment slices of known wet volume after drying at $60^{\circ} \mathrm{C}$ for $3 \mathrm{~d}$.

\section{Depth integration of data and statistical analysis}

Depth-integrated values of photopigments, intracellular nitrate (expressed per $\mu \mathrm{g}$ chl a), porewater nitrate and local nitrate production rates were calculated from the respective vertical profiles. Depth-

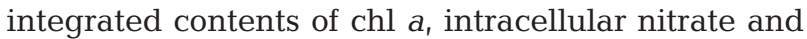
porewater nitrate were calculated by adding up the average concentration values of every depth interval of the vertical profile multiplied by the individual thickness of each depth interval. Depth-integrated net nitrate production rates were calculated by adding up the local production rates multiplied by the thickness of each depth interval of the productionconsumption profiles.

The depth-integrated contents of chl $a$, intracellular nitrate (expressed per $\mu \mathrm{g} \mathrm{chl} \mathrm{a),} \mathrm{porewater} \mathrm{nitrate}$ as well as the depth-integrated net nitrate production rates were compared among the 4 treatments. Oneway analyses of variance (ANOVAs) were run for each variable after confirming normality and homogeneity of variance of the data. If the null hypothesis was rejected, the Waller-Duncan post hoc test was used for pairwise comparisons. This test is based on Bayesian principles and uses the harmonic mean of different sample sizes. For the depth-integrated contents of intracellular nitrate, an additional $t$-test was run for the pairwise comparison between the control and Hediste treatments. All statistical analyses were carried out with the program SPSS Version 11.

\section{RESULTS}

\section{Sedimentary pool of intracellular nitrate}

Under in situ conditions, the sedimentary pool of intracellular nitrate showed a peak over 0 to $5 \mathrm{~cm}$ depth with a maximum concentration of $11.7 \mathrm{nmol}$ 


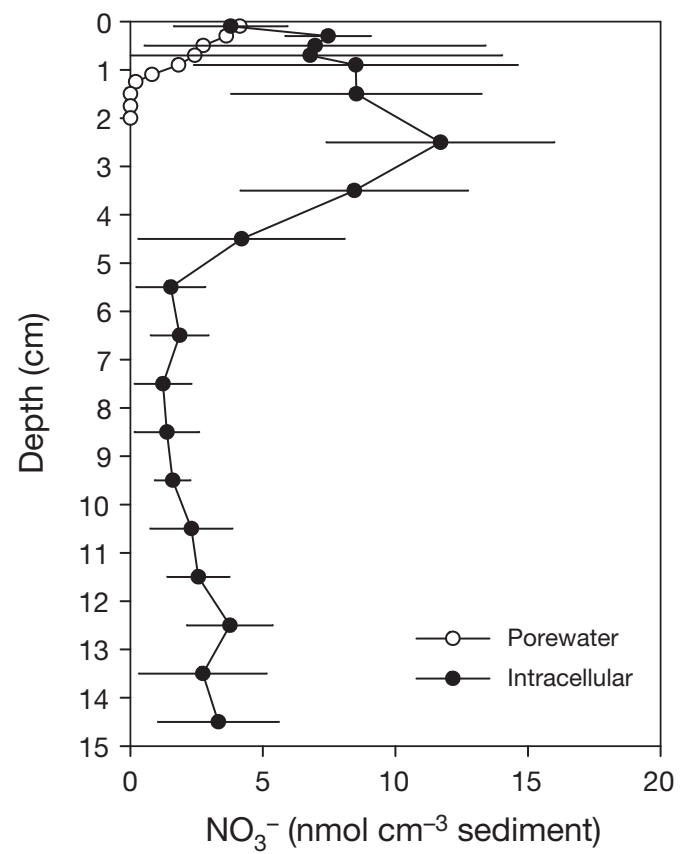

Fig. 1. In situ distribution of intracellular and porewater nitrate in intertidal sediment densely colonised by diatoms and burrowing macrofauna. Both intracellular nitrate and porewater nitrate concentrations are given in $\mathrm{nmol} \mathrm{\textrm {cm } ^ { - 3 }}$ sediment. Means $\pm \mathrm{SD}$ of $\mathrm{n}=3$ replicate profiles

$\mathrm{cm}^{-3}$ sediment (Fig. 1). Below $5 \mathrm{~cm}$, the intracellular nitrate concentration was relatively constant around $2.5 \mathrm{nmol} \mathrm{cm} \mathrm{cm}^{-3}$ sediment to the depth of $15 \mathrm{~cm}$ (Fig. 1). In contrast, the porewater nitrate concentration was highest at the sediment-water interface (up to $4.1 \mathrm{nmol} \mathrm{\textrm {cm } ^ { - 3 }}$ sediment) and decreased rapidly to 0 within the upper $1.5 \mathrm{~cm}$ of the sediment (Fig. 1).

In the microcosms, the sedimentary pools of intracellular nitrate showed the highest concentrations at the surface and then decreased gradually with depth in all treatments (Fig. 2A-D). Intracellular nitrate concentrations were generally higher and also extended to greater depth in the Hediste and ammonium treatments than in the control and Hediste + ATU treatments. The highest concentration of $71 \mathrm{nmol} \mathrm{cm}{ }^{-3}$ sediment was observed in the ammonium treatment (Fig. 2C).

While intracellular nitrate was detected in many of the sediment layers, it was totally absent from other layers. In contrast, organic matter was homogenously distributed in all sediment layers because the sediment was thoroughly homogenised before it was added to the microcosms. From this we concluded that organic nitrogen compounds

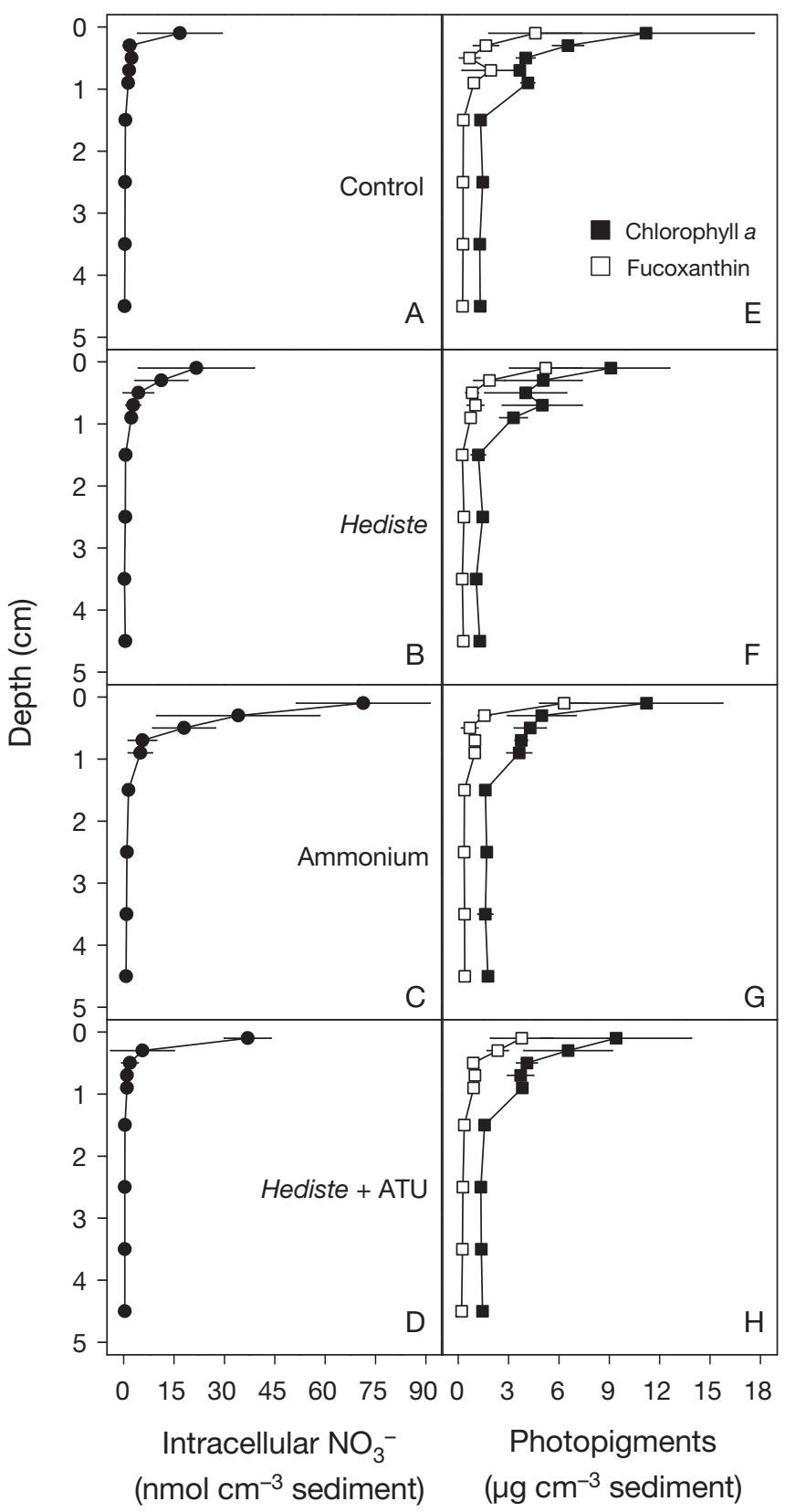

Fig. 2. Vertical distribution of (A-D) intracellular nitrate and $(\mathrm{E}-\mathrm{H})$ photopigments in coastal marine sediment incubated in laboratory flow-through microcosms for $3 \mathrm{wk}$. (A,E) Control sediment without Hediste diversicolor, $(\mathrm{B}, \mathrm{F})$ sediment colonised by $H$. diversicolor, $(\mathrm{C}, \mathrm{G})$ sediment without $H$. diversicolor, overlain with ammonium-enriched water and $(\mathrm{D}, \mathrm{H})$ sediment colonised by $H$. diversicolor, overlain by allylthiourea (ATU)-treated water. Means \pm SD of $n=4$ replicate cores

that were potentially extracted and degraded by the extreme temperature changes were not converted to nitrate, which would have produced false positive results. 


\section{Photopigment distribution in the sediment}

The vertical distributions of marker pigments of diatoms, viz. chl a and fucoxanthin, were similar in all treatments, with the highest pigment concentrations at the sediment surface and a gradual decrease down to $5 \mathrm{~cm}$ depth (Fig. 2E-H). Fucoxanthin was present in all sediment slices, indicating the presence of viable diatoms even in relatively deep sediment layers. In the upper $2 \mathrm{~mm}$ of the sediment, the fucoxanthin to chl a ratio was particularly high (i.e. 0.4 to 0.6 ) and suggested that the photosynthetically active community was dominated by diatoms (Lucas \& Holligan 1999), which was also confirmed by qualitative microscopic examination. Average concentrations of the 2 photopigments within each of the 9 sediment layers were linearly correlated with average concentrations of intracellular nitrate (Fig. 3).

\section{Porewater concentrations of oxygen and nitrate}

The oxygen profiles were identical in all treatments, except in the sediment of the Hediste + ATU treatment, where oxygen penetrated deeper. Diffusionreaction modelling revealed no significant net oxygen production due to microalgal photosynthesis at the sediment surface at which the light intensity was $50 \mu \mathrm{mol}$ photons $\mathrm{m}^{-2} \mathrm{~s}^{-1}$ (data not shown). The nitrate concentration profiles showed surface peaks indicative of nitrate production by nitrification in all treatments, except the Hediste + ATU treatment (Fig. 4A-D). Diffusion-reaction modelling revealed net production of nitrate in the oxic sediment layer of the control, Hediste and ammonium treatments (Fig. 4E-G), but not in the Hediste + ATU treatment (Fig. 4H). Below the oxic surface layer, net nitrate consumption by bacteria and/or microalgae occurred, which did not show any significant differences between all non-inhibited treatments, but which was very low in the Hediste + ATU treatment (Fig. 4E-H). It should be noted that net nitrate production and consumption might also have occurred inside the Hediste burrows, but this microbial activity was not measured with the microsensor approach. The nitrate concentration in the water column of the Hediste + ATU treatment was lower than in the natural North Sea water due to the inhibition of nitrification by ATU (Fig. 4A-D, Table 1). The ammonium concentration in the water column was highest in the ATU-inhibited treatment, intermediate in the Ammonium treatment and lowest in the Control and Hediste treatments (Table 1).

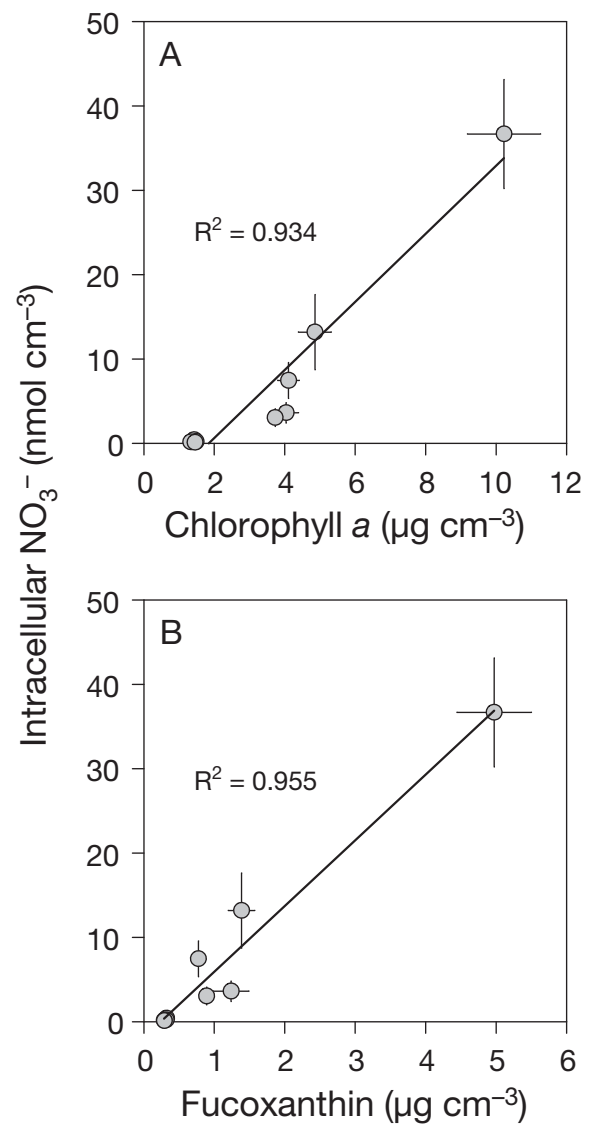

Fig. 3. Correlation of intracellular nitrate with (A) chlorophyll $a$ and (B) fucoxanthin in sediment cores taken from the 4 laboratory microcosms. Nitrate and pigment contents were averaged for each of the 9 sediment layers analysed (cf. Fig. 2). Error bars show SE for each sediment layer. $\mathrm{R}^{2}$ is Pearson's coefficient for linear correlations

\section{Depth-integrated contents of nitrate and photopigments}

Significant differences among the 4 treatments were found with respect to the depth-integrated contents of intracellular nitrate (expressed per $\mu \mathrm{g} \mathrm{chl} \mathrm{a),}$ porewater nitrate and net nitrate production rates (ANOVA: $F_{3,12}=19.7, \mathrm{p}<0.001, F_{3,25}=12.8, \mathrm{p}<0.001$ and $F_{3,25}=12.1, \mathrm{p}<0.001$, respectively) (Fig. 5A-C). In contrast, no significant differences among the 4 treatments were found with respect to the depthintegrated contents of chl a (ANOVA: $F_{3,12}=0.8, \mathrm{p}=$ 0.512) (Fig. 5D) and fucoxanthin (ANOVA: $F_{3,12}=2.6$, $\mathrm{p}=0.097$, data not shown). The porewater nitrate contents and the net nitrate production rate were significantly higher in the Hediste than in the control treatment (Waller-Duncan post hoc test, Fig. 5B,C). Also, the intracellular nitrate content (expressed per $\mu \mathrm{g} \mathrm{chl} \mathrm{a)} \mathrm{was} \mathrm{significantly} \mathrm{higher} \mathrm{in} \mathrm{the} \mathrm{Hediste} \mathrm{than}$ in the control treatment, but only in a pairwise com- 


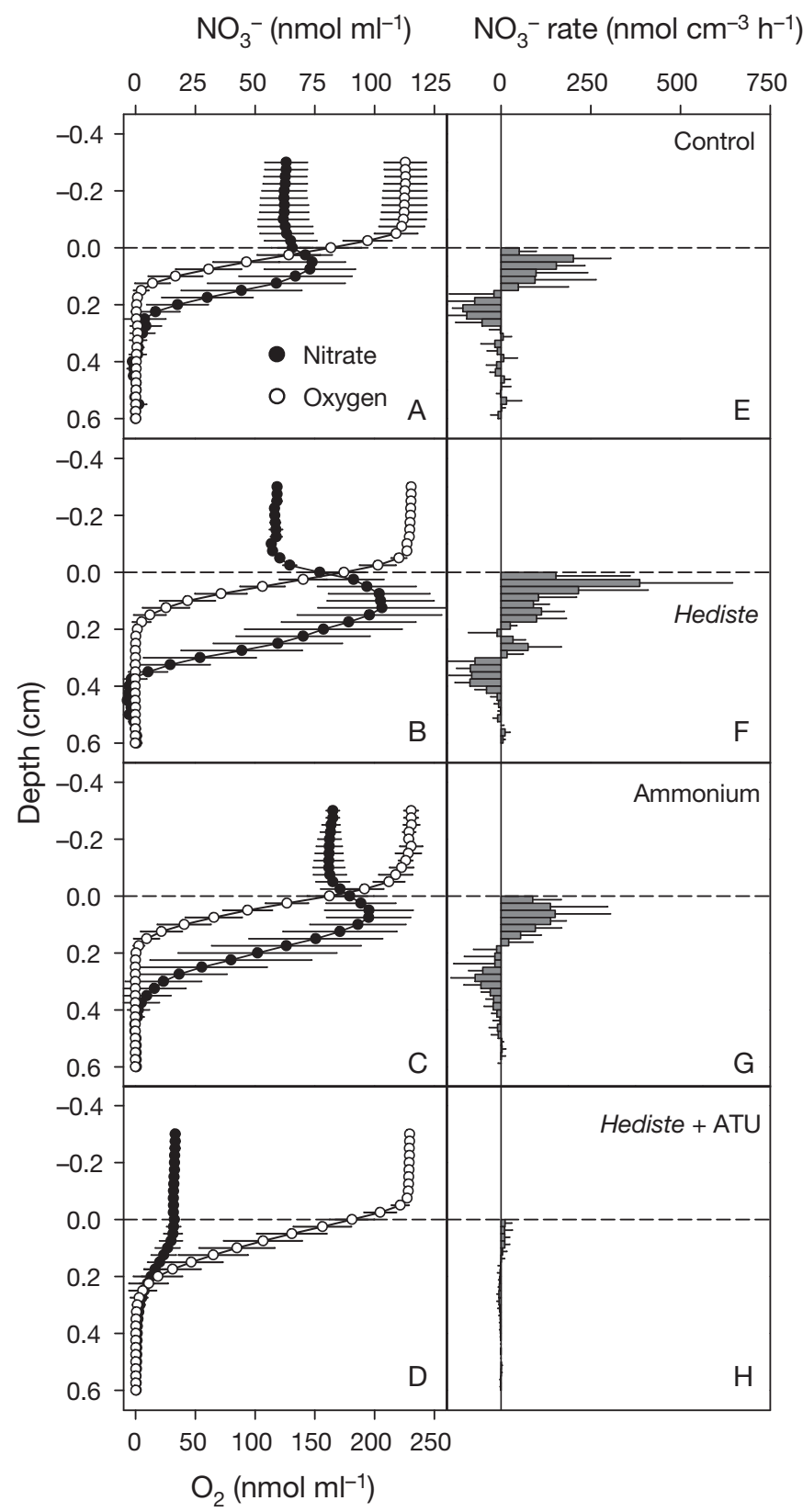

Fig. 4. (A-D) Vertical microprofiles of porewater oxygen and nitrate in laboratory sediment microcosms and $(\mathrm{E}-\mathrm{H})$ nitrate conversion rates derived from the microprofiles. Treatments as described in Fig. 2. Dashed line indicates the sedimentwater interface. Positive and negative rates correspond to net production and consumption of nitrate, respectively.

Means $+\mathrm{SD}$ of $\mathrm{n}=4$ to 14 replicate profiles are shown

parison that excluded the ammonium treatment with its extraordinarily high average intracellular nitrate content (Student's $t$-test: $t_{6}=-2.8, \mathrm{p}<0.05$ ) (Fig. 5A). In the ammonium treatment mimicking ammonium excretion by $H$. diversicolor, the intracellular and porewater nitrate contents (but not nitrate production and chl a) were significantly higher than in
Table 1. Mean $( \pm \mathrm{SD})$ ammonium and nitrate concentrations (in $\mu \mathrm{mol} \mathrm{l}^{-1}$ ) in the water column of 4 sediment microcosms over the incubation period of $3 \mathrm{wk}$. Treatments are described in the legend of Fig. 2. ATU: allylthiourea

\begin{tabular}{|lrl|}
\hline Treatment & $\mathrm{NH}_{4}{ }^{+}$ & $\mathrm{NO}_{3}{ }^{-}$ \\
\hline Control & $1.2(0.7)$ & $34.1(9.8)$ \\
Hediste & $2.7(2.2)$ & $44.8(7.9)$ \\
Ammonium & $11.2(8.9)$ & $46.2(17.6)$ \\
Hediste + ATU & $33.5(6.1)$ & $14.0(5.4)$ \\
\hline
\end{tabular}

the control treatment (Waller-Duncan post hoc test, Fig. 5A-D). In the Hediste + ATU treatment, the intracellular and porewater nitrate contents as well as the net nitrate production rate (but not chl a) were significantly lower than in the Hediste and ammonium treatments in which ammonium was abundant and could be nitrified (Waller-Duncan post hoc test, Fig. 5A-D).

The variability of depth-integrated profiles within each treatment was high for the punctual oxygen and nitrate microsensor profiles (i.e. coefficients of variation [CVs] $=29$ to 39 and 31 to $40 \%$, respectively) and low for chl $a$ and fucoxanthin profiles that were analysed in sediment cores that integrated over ca. $5 \mathrm{~cm}^{2}$ of sediment surface (i.e. $\mathrm{CVs}=2$ to 22 and 7 to $15 \%$, respectively). Intracellular nitrate that was also analysed in sediment cores took an intermediate position, with CVs of 24 to $33 \%$ for cores collected in the microcosms. The CV was relatively high $(42 \%)$ only for the cores collected in situ.

\section{DISCUSSION}

\section{Intracellular nitrate in intertidal sediment}

A large pool of intracellular nitrate was discovered in the sediment of an intertidal flat in the German Wadden Sea. Intracellular nitrate exceeded porewater nitrate levels and was also present at depths where porewater nitrate was depleted. The high abundance of diatoms in this and other intertidal flats (MacIntyre et al. 1996) suggests that nitrate is stored in benthic phototrophic microorganisms. Correlative evidence for nitrate storage in diatoms was obtained by photopigment analysis in the intertidal sediment incubated in laboratory microcosms. Sedimentary pools of intracellular nitrate due to nitrate storage by diatoms may be a widespread phenomenon in coastal marine sediments, since diatoms dominate microphytobenthic communities in intertidal flats 

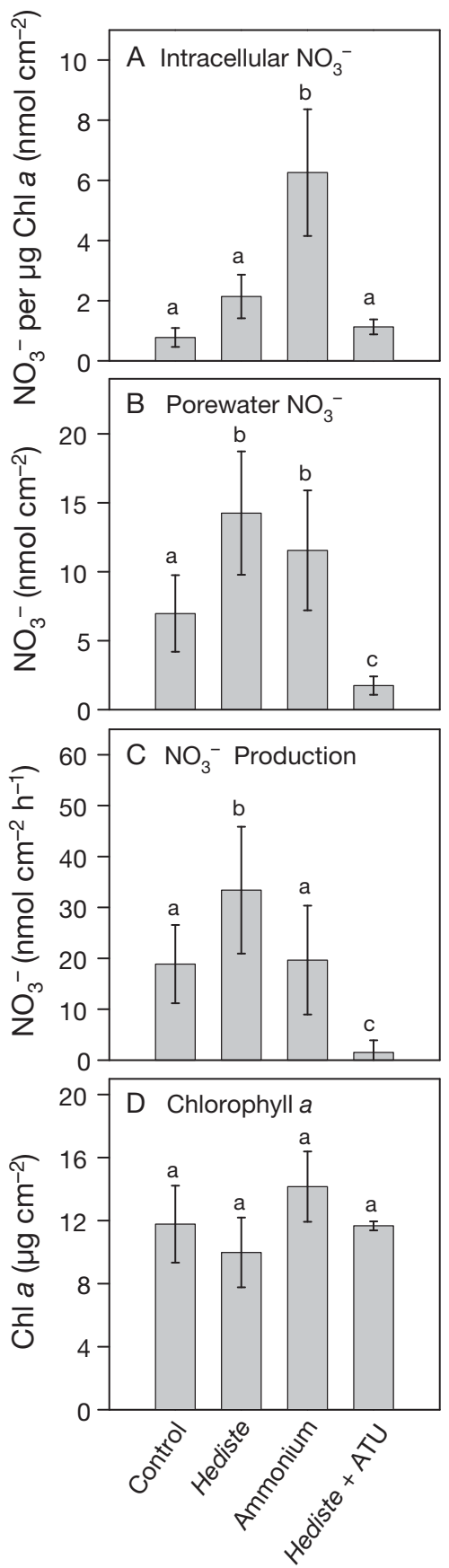

Fig. 5. Depth-integrated (A) intracellular nitrate, expressed per $\mu$ g chlorophyll (chl) $a$, (B) porewater nitrate, (C) net nitrate production and (D) $\mathrm{chl} a$. Treatments are described in Fig. 2. Means $+\mathrm{SD}$ of $\mathrm{n}=3$ to 14 replicate measurements are shown. Treatments with different lower case letters have significantly different means (ANOVA, Waller-Duncan post hoc test)

(MacIntyre et al. 1996) and are able to store nitrate intracellularly (Garcia-Robledo et al. 2010, Kamp et al. 2011). Nevertheless, the presence of intracellular nitrate might also be linked to large sulphur bacteria (Sayama 2001), but in the sulphide-poor intertidal sediment near Dorum-Neufeld (Jahn \& Theede 1997), these microorganisms were not present, as confirmed by microscopy. Many benthic foraminifera are able to store nitrate, but obviously not the species occurring in German Wadden Sea sediments (Risgaard-Petersen et al. 2006, Piña-Ochoa et al. 2010).

The maximum concentration of intracellular nitrate was found in the upper $5 \mathrm{~cm}$ of the intertidal sediment, which contrasts with the thin layer of intracellular nitrate at the surface of other coastal marine sediments (Lomstein et al. 1990, Garcia-Robledo et al. 2010). Interestingly, the layer of high intracellular nitrate concentrations is often much thicker than the photosynthetically active layer (Fenchel \& Straarup 1971). This broad distribution of intracellular nitrate must be caused by the presence of diatoms in deep, aphotic sediment layers. The gliding motility of diatoms allows them to migrate vertically in the sediment, but only down to depths of a few millimetres. In contrast, passive burial of diatoms may relocate them several centimetres or decimetres into the sediment. Known burial mechanisms of small microalgal cells are advective porewater flow in permeable sandy sediments (Huettel \& Rusch 2000, Ehrenhauss et al. 2004) and bioturbation by animals such as the polychaetes Hediste diversicolor and Arenicola marina that were abundant at the time of sampling the intertidal flat.

\section{Effect of Hediste diversicolor on intracellular nitrate}

In the laboratory microcosms, benthic diatoms were most probably the main nitrate-storing organisms because intracellular nitrate concentrations correlated well with distributions of chl a and fucoxanthin. Large sulphur bacteria and foraminifera probably did not contribute substantially to the sedimentary pool of intracellular nitrate for the reasons given above. The intracellular nitrate pool was larger in the Hediste than in the control microcosm, even though diatom density and distribution were the same in the 2 treatments. This means that $H$. diversicolor increased the average concentration of intracellular nitrate in the diatom cells rather than changing the cell density of nitrate-storing diatoms. The presence of $H$. diversicolor also enhanced the sedimentary nitrification rate and enlarged the zone in which nitrification took place. Nitrification might be stimulated by the increased oxygen availability due to searching and foraging activities of the polychaete. In deeper sediment layers, burrow ventilation and 
ammonium excretion may increase both oxygen and ammonium availability and consequently nitrification in the thin oxic layer of the worm burrows (Mayer et al. 1995, Nielsen et al. 2004). However, the excretion activity of the polychaete may also affect nitrification at the sediment surface if a substantial fraction of the ammonium excreted is expelled into the water column due to the worm's ventilation activity. This effect might be quantitatively important in shallow coastal ecosystems and reinforced in a recirculating system as used here. In line with this reasoning, the ammonium treatment, meant to mimic the ammonium excretion by $H$. diversicolor increased the porewater and intracellular nitrate concentrations close to the sediment surface. The increased availability of ammonium alone was sufficient to enlarge the nitrate pools, while the increased availability of oxygen seemed to be less important for the stimulation of nitrification.

The microcosm experiment revealed that diatoms take up and store more nitrate intracellularly when nitrifying bacteria produce nitrate in the immediate environment of the algae, maybe because of the efficient transport of nitrate within the oxic sediment layer. The tight relationship between sedimentary nitrification and the storage of intracellular nitrate by diatoms was demonstrated by the addition of the nitrification inhibitor ATU to the second Hediste treatment. No stimulatory effect of $H$. diversicolor on the intracellular and porewater nitrate pools occurred in the presence of ATU, despite the worms' ammonium excretion and sediment oxygenation.

The flux of DIN between the water column and the sediment probably affected the nitrate pools in the sediment. The DIN concentrations in the water column that drove these fluxes differed among the 4 treatments in an expected way. The North Sea water supplied to the microcosms contained ca. $40 \mu_{\mathrm{mol}} \mathrm{l}^{-1}$ nitrate, and the average nitrate concentration remained close to this concentration, except for the Hediste + ATU treatment where it decreased in the water column. This observation was in line with nitrification being inhibited and nitrate consumption going on in the sediment. Together, the missing nitrate production in the sediment and the lower nitrate flux from the water column explain the small sedimentary pool of intracellular nitrate observed in the ATU-treated sediment. The North Sea water supplied to the microcosms contained ca. 1 to $2 \mu \mathrm{mol} \mathrm{l}^{-1}$ ammonium, and this concentration remained unchanged, except in the ammonium treatment, where it was deliberately adjusted to a concentration higher than in natural North Sea water and also in the
Hediste + ATU treatment, where it increased due to the worms' ammonium excretions and nitrification being inhibited in the sediment. The possible ammonium flux from the water column into the sediment increased the intracellular nitrate pool only in the ammonium treatment, but not in the Hediste + ATU treatment, which underlines that ammonium must be nitrified to nitrate in the sediment to exert a measurable effect on the intracellular nitrate pool.

\section{Extrapolation to natural conditions}

After the equilibration time of $10 \mathrm{~d}$, worm distribution in the sediment microcosms was relatively homogenous, while the diatoms that were visible on the sediment surface occurred in patches. The very thin tip of microsensors measures chemical gradients in a very small spot, and these gradients may differ considerably even between neighbouring spots. To arrive at representative oxygen and nitrate gradients, microprofiles were repeated at as many randomly chosen spots as possible in each microcosm (i.e. up to 14). In contrast, sediment cores with a diameter of $2.5 \mathrm{~cm}$ integrate the measured parameter over an area of ca. $5 \mathrm{~cm}^{2}$. Replicate sediment cores were thus expected to be more similar than replicate microprofiles, and therefore coring was repeated only 4 times in each microcosm. In fact, the observed within-treatment variability of depth-integrated profiles was high for microsensor data, intermediate for intracellular nitrate data and low for pigment data. In all cases, the within-treatment variability was low enough to allow for comparisons between the treatments, and it was also lower than that observed under in situ conditions.

The intracellular nitrate concentrations in the sediment microcosms were in the range of naturally occurring concentrations in coastal marine sediments (Garcia-Robledo et al. 2010, Høgslund et al. 2010). The difference in the vertical distribution of intracellular nitrate concentrations between the sediment microcosms and the field site are probably due to differences in the flow regime (i.e. tidal currents versus continuous flow) and the community of burrowing macrofauna (i.e. single-species versus multi-species community). In the sediment microcosms, the bioturbation and bioirrigation activities of Hediste diversicolor did not lead to substantial burial of diatoms. The density of $H$. diversicolor in the sediment microcosms was in the lower range of densities reported for marine sediments (Scaps 2002). The effect of $H$. diversicolor on intracellular nitrate pools might thus 
be even stronger at higher worm densities. The nutrient concentrations were in the range of naturally occurring concentrations in the Wadden Sea (Kieskamp et al. 1991, van Beusekom et al. 2008). Chl a concentrations in the sediment microcosms were in the normal range (MacIntyre et al. 1996). The observed effects of $H$. diversicolor on the sedimentary pool of intracellular nitrate might thus be representative of intertidal flats of similar sediment composition. It is noteworthy that the quantitative importance of intracellular nitrate will be particularly high in low-porosity sediments as studied here, whereas porewater nitrate is likely more important in highporosity sediments such as mud.

\section{Possible fate of intracellular nitrate}

When integrating the vertical profiles over depth, the intertidal sediment contained $619 \mu \mathrm{mol} \mathrm{m}^{-2}$ intracellular nitrate and $87 \mu \mathrm{mol} \mathrm{m}{ }^{-2}$ porewater nitrate. Intracellular nitrate may thus sustain nitrate-consuming processes in the sediment longer or at a higher rate than porewater nitrate. The diatoms themselves use intracellular nitrate for assimilation (Lomas \& Glibert 2000), but they have also been shown to reduce it to ammonium in a dissimilatory process that is induced by dark, anoxic conditions (Kamp et al.
2011). Both diatoms and intracellular nitrate were detected in anoxic sediment layers of the sediment microcosms, and thus diatoms do not entirely consume their intracellular nitrate content under dark, anoxic conditions. It may be speculated that some nitrate leaks out of the diatom cells (e.g. upon lysis following the freezing of sediment at low tide during winter) and fuels anaerobic nitrate respiration by other microorganisms in the sediment. Denitrification rates reported for intertidal sediments in the Wadden Sea range from 0.2 to $190 \mu \mathrm{mol} \mathrm{N} \mathrm{m}{ }^{-2} \mathrm{~h}^{-1}$ (Kieskamp et al. 1991, Jensen et al. 1996, Gao et al. 2010). Hence, intracellular nitrate from diatoms might sustain denitrification in intertidal sediments for 3 to $129 \mathrm{~d}$. Both anaerobic and aerobic denitrification occur in Wadden Sea sediments (Gao et al. 2010) and could be fuelled by intracellular nitrate from diatoms that are present in both oxic and anoxic sediment layers.

\section{Conceptual model of macrofauna effect on intracellular nitrate}

We propose a mechanism of nitrogen cycling in coastal marine sediments in which organisms from different trophic levels interact in converting particulate organic nitrogen (PON) to nitrate that is stored in

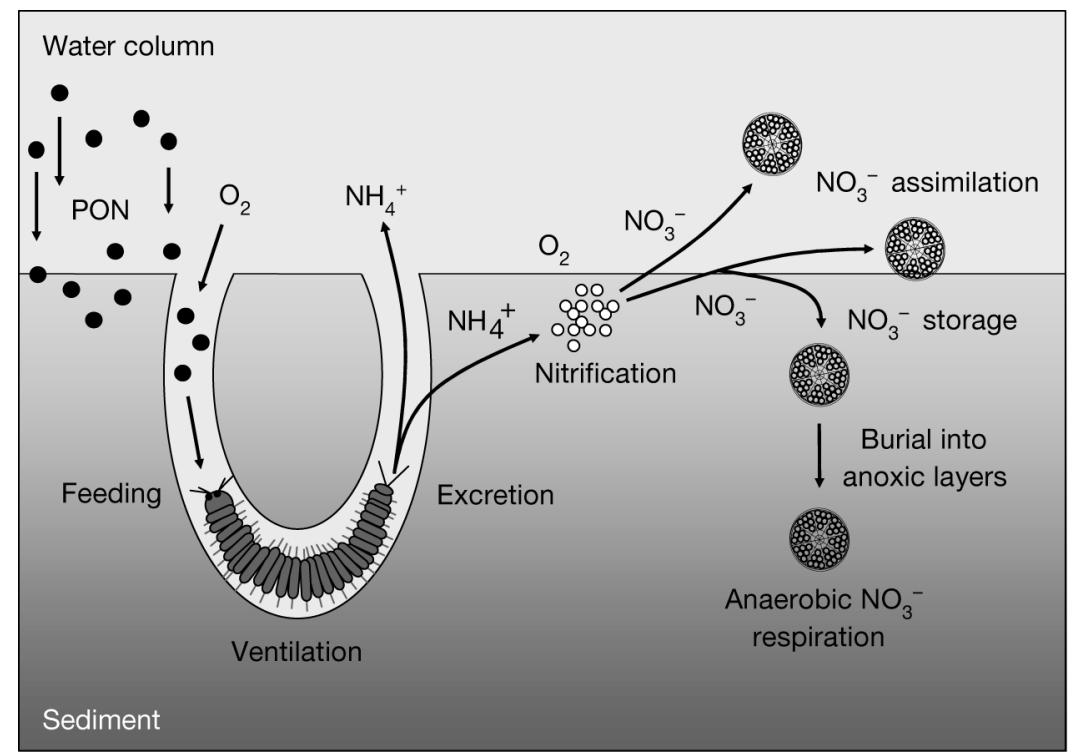

Fig. 6. Conceptual model of nitrogen cycling in intertidal sediments as affected by nitrate-storing diatoms and burrowing polychaetes. Worms feed on organic matter (PON: particulate organic nitrogen, black circles) from the water column or the sediment surface, excrete ammonium and oxygenate the sediment by their foraging, burrowing and ventilating activities. In doing so, worms enhance the activity of nitrifying bacteria (white circles) that oxidise ammonium to nitrate in oxic sediment layers. Nitrate is taken up and stored intracellularly by diatoms (perforated discs). The sedimentary pool of intracellular nitrate can be used for nitrogen assimilation or for anaerobic nitrate respiration in anoxic sediment layers 
sedimentary microorganisms (Fig. 6). Burrowing macrofauna feed on organic matter and excrete ammonium or nitrogen-rich organic compounds like mucus or silk. Additionally, they oxygenate the sediment by their foraging, burrowing and ventilating activities, which results in additional interface area and enhanced solute fluxes. Macrofauna thereby stimulate the activity of nitrifying bacteria that oxidise ammonium to nitrate in the oxic sediment layers. Nitrate is then taken up by microalgae (e.g. diatoms) and stored intracellularly. This mechanism leads to a change in the forms of nitrogen (nitrate versus ammonium and PON) and in the compartmentalisation of nitrogen (intracellular versus extracellular). The conversion of PON into reactive oxidised nitrogen may fuel benthic primary production or serve as an electron acceptor in anoxic sediment layers.

It remains to be investigated whether macrofauna also influence the fate of intracellular nitrate in coastal marine sediments. It may be speculated that macrofaunal activities will determine whether nitrate-storing microorganisms use their intracellular nitrate themselves or whether it is made available to other sediment microorganisms. Sediment reworking and burrow construction by macrofauna may relocate microphytobenthos within the sediment and expose it to different microenvironmental conditions (e.g. from light to dark, or from oxic to anoxic conditions). In the light, the microalgae probably use intracellular nitrate for nitrogen assimilation (Lomas \& Glibert 2000). If buried by macrofauna to dark and anoxic conditions, the microalgae may use their intracellular nitrate for dissimilatory nitrate reduction to ammonium to meet the energy demand for entering a resting stage for long-term survival (Kamp et al. 2011). Conversely, macrofauna that feed on microphytobenthos may cause the lysis of nitrate-storing cells in the gut (Smith et al. 1996). Denitrifying bacteria in the gut can use nitrate leaking out of the lysing microalgal cells and produce nitrous oxide and dinitrogen gas which are emitted from the animal (Stief et al. 2009, Heisterkamp et al. 2010). Nitrate that is not used in the gut will be excreted and can be used by sediment bacteria in the immediate surroundings of macrofauna burrows as possible hotspots of nitrate respiration.

Acknowledgements. We thank the technicians of the Max Planck Institute for Marine Microbiology for the construction of microsensors. M. Huettel is acknowledged for inspiring discussions. This study was financially supported by a grant from the German Science Foundation awarded to P.S. (STI 202/6) and by the Max Planck Society, Germany.

\section{LITERATURE CITED}

Berner RA (1980) Early diagenesis: a theoretical approach. Princeton University Press, Princeton, NJ

> Blanchard GF, Guarini JM, Orvain F, Sauriau PG (2001) Dynamic behaviour of benthic microalgal biomass in intertidal mudflats. J Exp Mar Biol Ecol 264:85-100

Bouchet VM, Sauriau P, Debenay J, Mermillod-Blondin F, Schmidt S, Amiard J, Dupas B (2009) Influence of the mode of macrofauna-mediated bioturbation on the vertical distribution of living benthic foraminifera: first insight from axial tomodensitometry. J Exp Mar Biol Ecol 371: 20-33

> Boudreau BP (1996) The diffusive tortuosity of fine-grained unlithified sediments. Geochim Cosmochim Acta 60: 3139-3142

> Braman RS, Hendrix SA (1989) Nanogram nitrite and nitrate determination in environmental and biological materials by vanadium(III) reduction with chemiluminescence detection. Anal Chem 61:2715-2718

Bungay HR, Whalen WJ, Sanders WM (1969) Microprobe techniques for determining diffusivities and respiration rates in microbial slime systems. Biotechnol Bioeng 11: 765-772

Christensen B, Vedel A, Kristensen E (2000) Carbon and nitrogen fluxes in sediment inhabited by suspensionfeeding (Nereis diversicolor) and non-suspension feeding (N. virens) polychaetes. Mar Ecol Prog Ser 192:203-217

de Beer D, Wenzhofer F, Ferdelman TG, Boehme SE and others (2005) Transport and mineralization rates in North Sea sandy intertidal sediments, Sylt-Rømø Basin, Wadden Sea. Limnol Oceanogr 50:113-127

> Ehrenhauss S, Witte U, Buhring SL, Huettel M (2004) Effect of advective pore water transport on distribution and degradation of diatoms in permeable North Sea sediments. Mar Ecol Prog Ser 271:99-111

> Fenchel T, Straarup BJ (1971) Vertical distribution of photosynthetic pigments and the penetration of light in marine sediments. Oikos 22:172-182

> Gao H, Schreiber F, Collins G, Jensen MM and others (2010) Aerobic denitrification in permeable Wadden Sea sediments. ISME J 4:417-426

- Garcia-Robledo E, Corzo A, Papaspyrou S, Jimenez-Arias JL, Villahermosa D (2010) Freeze-lysable inorganic nutrients in intertidal sediments: dependence on microphytobenthos abundance. Mar Ecol Prog Ser 403:155-163

> Gardner WS, Briones EE, Kaegi EC, Rowe GT (1993) Ammonium excretion by benthic invertebrates and sedimentwater nitrogen flux in the Gulf of Mexico near the Mississippi River outflow. Estuaries 16:799-808

Hall GH (1984) Measurement of nitrification rates in lake sediments: comparison of the nitrification inhibitors nitrapyrin and allylthiourea. Microb Ecol 10:25-36

Hall POJ, Aller RC (1992) Rapid, small-volume, flow injection analysis for $\Sigma \mathrm{CO}_{2}$, and $\mathrm{NH}_{4}{ }^{+}$in marine and freshwaters. Limnol Oceanogr 37:1113-1119

Heisterkamp IM, Schramm A, de Beer D, Stief P (2010) Nitrous oxide production associated with coastal marine invertebrates. Mar Ecol Prog Ser 415:1-9

> Herman PMJ, Middelburg JJ, Widdows J, Lucas CH, Heip CHR (2000) Stable isotopes as trophic tracers: combining field sampling and manipulative labelling of food resources for macrobenthos. Mar Ecol Prog Ser 204:79-92

Høgslund S, Revsbech NP, Cedhagen T, Nielsen LP, Gallardo VA (2008) Denitrification, nitrate turnover, and aer- 
obic respiration by benthic foraminiferans in the oxygen minimum zone off Chile. J Exp Mar Biol Ecol 359:85-91

Høgslund S, Revsbech NP, Kuenen JG, Jørgensen BB and others (2009) Physiology and behaviour of marine Thioploca. ISME J 3:647-657

Høgslund S, Nielsen JL, Nielsen LP (2010) Distribution, ecology and molecular identification of Thioploca from Danish brackish water sediments. FEMS Microbiol Ecol 73:110-120

> Huettel M, Rusch A (2000) Transport and degradation of phytoplankton in permeable sediment. Limnol Oceanogr 45:534-549

Jahn A, Theede H (1997) Different degrees of tolerance to hydrogen sulphide in populations of Macoma balthica (Bivalvia, Tellinidae). Mar Ecol Prog Ser 154:185-196

Jensen KM, Jensen MH, Kristensen E (1996) Nitrification and denitrification in Wadden Sea sediments (Königshafen, Island of Sylt, Germany) as measured by nitrogen isotope pairing and isotope dilution. Aquat Microb Ecol 11:181-191

Kamp A, de Beer D, Nitsch JL, Lavik G, Stief P (2011) Diatoms respire nitrate to survive dark and anoxic conditions. Proc Natl Acad Sci USA 108:5649-5654

Kieskamp WM, Lohse L, Epping E, Helder W (1991) Seasonal variation in denitrification rates and nitrous oxide fluxes in intertidal sediments of the western Wadden Sea. Mar Ecol Prog Ser 72:145-151

Kristensen E (2001) Impact of polychaetes (Nereis spp. and Arenicola marina) on carbon biogeochemistry in coastal marine sediments. Geochem Trans 2:92-103

Larsen LH, Kjær T, Revsbech NP (1997) A microscale $\mathrm{NO}_{3}{ }^{-}$ biosensor for environmental applications. Anal Chem 69: 3527-3531

Li YH, Gregory S (1974) Diffusion of ions in sea water and deep-sea sediments. Geochim Cosmochim Acta 38:703-714

Lomas MW, Glibert PM (2000) Comparisons of nitrate uptake, storage, and reduction in marine diatoms and flagellates. J Phycol 36:903-913

Lomstein E, Jensen MH, Sørensen J (1990) Intracellular $\mathrm{NH}_{4}{ }^{+}$and $\mathrm{NO}_{3}{ }^{-}$pools associated with deposited phytoplankton in a marine sediment (Aarhus Bight, Denmark). Mar Ecol Prog Ser 61:97-105

Lucas CH, Holligan PM (1999) Nature and ecological implications of algal pigment diversity on the Molenplaat tidal flat (Westerschelde estuary, SW Netherlands). Mar Ecol Prog Ser 180:51-64

MacIntyre HL, Geider RJ, Miller DC (1996) Microphytobenthos: the ecological role of the 'secret garden' of unvegetated, shallow-water marine habitats. I. Distribution, abundance, and primary production. Estuaries 19:186-201

Editorial responsibility: Pei-Yuan Qian, Kowloon, Hong Kong SAR
Mayer MS, Schaffner L, Kemp WM (1995) Nitrification potentials of benthic macrofaunal tubes and burrow walls: effects of sediment $\mathrm{NH}_{4}{ }^{+}$and animal irrigation behaviour. Mar Ecol Prog Ser 121:157-169

> Nielsen OI, Gribsholt B, Kristensen E, Revsbech NP (2004) Microscale distribution of oxygen and nitrate in sediment inhabited by Nereis diversicolor: spatial patterns and estimated reaction rates. Aquat Microb Ecol 34:23-32

> Piña-Ochoa E, Høgslund S, Geslin E, Cedhagen T and others (2010) Widespread occurrence of nitrate storage and denitrification among Foraminifera and Gromiida. Proc Natl Acad Sci USA 107:1148-1153

Preisler A, de Beer D, Lichtschlag A, Lavik G, Boetius A, Jørgensen BB (2007) Biological and chemical sulphide oxidation in a Beggiatoa inhabited marine sediment. ISME J 1:341-353

> Revsbech NP (1989) An oxygen microsensor with a guard cathode. Limnol Oceanogr 34:474-478

Risgaard-Petersen N, Langezaal AM, Ingvardsen S, Schmid $\mathrm{MC}$ and others (2006) Evidence for complete denitrification in a benthic foraminifer. Nature 443:93-96

Sayama M (2001) Presence of nitrate-accumulating sulphur bacteria and their influence on nitrogen cycling in a shallow coastal marine sediment. Appl Environ Microbiol 67: 3481-3487

Scaps P (2002) A review of the biology, ecology and potential use of the common ragworm Hediste diversicolor (O.F. Müller) (Annelida: Polychaeta). Hydrobiologia 470: 203-218

Schulz HN, Jørgensen BB (2001) Big bacteria. Annu Rev Microbiol 55:105-137

Smith D, Hughes RG, Cox EJ (1996) Predation of epipelic diatoms by the amphipod Corophium volutator and the polychaete Nereis diversicolor. Mar Ecol Prog Ser 145: 53-61

Stief P, de Beer D (2002) Bioturbation effects of Chironomus riparius on the benthic $\mathrm{N}$-cycle as measured using microsensors and microbiological assays. Aquat Microb Ecol 27:175-185

Stief P, Poulsen M, Nielsen LP, Brix H, Schramm A (2009) Nitrous oxide emission by aquatic macrofauna. Proc Natl Acad Sci USA 106:4296-4300

Sundbäck K, Miles A (2000) Balance between denitrification and microalgal incorporation of nitrogen in microtidal sediments, NE Kattegat. Aquat Microb Ecol 22:291-300

> van Beusekom JEE, Weigelt-Krenz S, Martens P (2008) Longterm variability of winter nitrate concentrations in the northern Wadden Sea driven by freshwater discharge, decreasing riverine loads and denitrification. Helgol Mar Res 62:49-57

Submitted: May 13, 2011; Accepted: October 24, 2011 Proofs received from author(s): January 9, 2012 